\title{
CHANGES IN THE MAIN VEGETATION TYPES OF CHILE PREDICTED UNDER CLIMATE CHANGE BASED ON A PRELIMINARY STUDY: MODELS, UNCERTAINTIES AND ADAPTING RESEARCH TO A DYNAMIC BIODIVERSITY WORLD

\author{
PREDICCIONES DE CAMBIOS EN LOS PRINCIPALES TIPOS DE VEGETACIÓN \\ DE CHILE BAJO CAMBIO CLIMÁTICO BASADOS EN UN ESTUDIO \\ PRELIMINAR: MODELOS, INCERTIDUMBRES Y ADAPTACIÓN DE LA \\ INVESTIGACIÓN PARA UN MUNDO DE BIODIVERSIDAD DINÁMICA
}

Patricio Pliscoff ${ }^{1}$, Mary T. K. Arroyo ${ }^{2} \&$ Lohengrin Cavieres $^{3}$

\section{RESUMEN}

Los efectos del cambio climático sobre la biodiversidad ocurren a diferentes niveles de organización (organismos, especies y ecosistemas). La vegetación se encuentra relacionada directamente con el clima, por lo que se espera que el calentamiento global altere la distribución de los tipos de vegetación para el futuro cercano. Usando un enfoque de envoltura bioclimática, los tipos de vegetación de Chile fueron modelados y proyectados usando escenarios del IPCC para el año 2080. Los resultados presentan diferentes transiciones entre los tipos de vegetación, en relación a su distribución latitudinal y altitudinal actual. Entre los cambios principales, se identifica el avance altitudinal de la vegetación alpina, la expansión hacia el sur del desierto absoluto y del matorral desértico sobre el bosque esclerófilo. Se esperan cambios en la representación relativa de las áreas protegidas dentro de los diferentes tipos de vegetación de Chile. Las limitaciones del ejercicio de modelación son discutidas junto a la necesidad de mejorar el conocimiento científico sobre procesos biológicos claves como dispersión y polinización. PRECIS.

Palabras clave: Cambio climático, Modelos de envoltura bioclimática, tipos de vegetación, MAXENT,

1 Department of Ecology and Evolution, Faculty of Biology and Medicine, University of Lausanne, Switzerland. patricio.pliscoff@unil.ch.

2 Institute of Ecology and Biodiversity (IEB), University of Chile. southern@uchile.cl.

3 University of Concepción and Institute of Ecology and Biodiversity (IEB). lcaviere@udec.cl. 


\begin{abstract}
Climate change effects on biodiversity occur at different level of organization (organisms, species and ecosystems). Vegetation type bears a close relationship with climate, such that global warming is expected to alter the distribution of major vegetation types in the near future. Using a bioclimatic envelope modeling approach, the major vegetation types of Chile were modeled and projected using IPCC scenarios for year 2080. The results show transitions among vegetation types in relation to their current latitudinal and altitudinal distribution. Major changes include an upward shift of the alpine vegetation and southward expansion of absolute desert and desert scrub into the present area of sclerophyllous forest. Changes in the relative representation of different vegetation types in Chile's protected areas can be expected. The limitations of modeling exercises are discussed along with need for better scientific knowledge on key biological processes such as dispersal and pollination.
\end{abstract}

Key words: Climate change, Bioclimatic envelope modeling, Vegetation Types, MAXENT, PRECIS.

\section{INTRODUCTION}

Anthropogenically-driven climate change is the product of increased $\mathrm{CO}_{2}$ and methane in the atmosphere as a result of the burning of fossil fuels, deforestation, and changing land-use patterns. Current models suggest that the earth could warm from between 1.8 and $4^{\circ} \mathrm{C}$ by 2090-2099 in relation to $1980-1999$, with accompanying changes in the distribution of precipitation and sea-level rises. Given the close relationship between climate and vegetation, profound changes in the distribution of vegetation types may be set into place globally during the present century. Indeed, the effects of climate change are already manifesting in some parts of the world. Comparisons of altitudinal ranges of plants species today with those registered around 100 years ago have established significant upward migration of plant species along altitudinal gradients in Europe (Lenoir et al. 2008), attributable to increases in temperature over this period and studies have recorded earlier flowering times in plants (Fitter et al. 2002). As a result of changing climate, over the next century, the IPCC (2007) reports with medium confidence that approximately 20 to $30 \%$ of species assessed so far are likely to be at increased risk of extinction if increases in global average warming exceed 1.5 to $2.5^{\circ} \mathrm{C}$ relative to $1980-1999$.

Given its enormous latitudinal extension, and steep altitudinal gradients, the diversity of vegetation found along the length of Chile is outstanding. Such diversity constitutes a useful model to detect how climate change will affect vegetation in the southern cone of the South American continent. Chile's vegetation is underpinned by a rich and endemic flora of 4985 species, many species of which are contained in the central Chilean Biodiversity Hotspot. Chile houses an island of temperate rainforest isolated from other forested areas in South America by around $1,000 \mathrm{~km}$, and the southernmost extension of temperate forest and alpine ecosystems in the world. The impact of climate change on these last-mentioned southern vegetation belts and any subsequent feedbacks on the climate of Antarctica, thus are of regional and global interest.

\section{METHODS}

As a first step towards understanding how Chile's vegetation will respond to climate change, using a synthetic version (based on broad vegetation formation distributions) of the recent vegetation scheme published by Luebert \& Pliscoff (2006), we modeled Chile's current vegetation under present climate conditions and under the A2 and B2 IPCC climate scenarios using the DGF $(2006)^{1}$ regional analysis of climate variability during the $21^{\text {st }}$ century at the $25 \mathrm{~km}$ pixel resolution, which is based on the PRECIS Model (Jones et al. 2004). Vegetation was modeled applying a bioclimatic envelope approach, using maximum entropy algorithm with software MAXENT 3.3.0 (Phillips et al. 2006) on the basis of the monthly values of 5 climatic variables

1 DGF, 2006. Estudio de la variabilidad Climática en Chile para el Siglo XXI. Informe Final, Departamento de Geofísica, Universidad de Chile, Santiago, $71 \mathrm{p}$. 


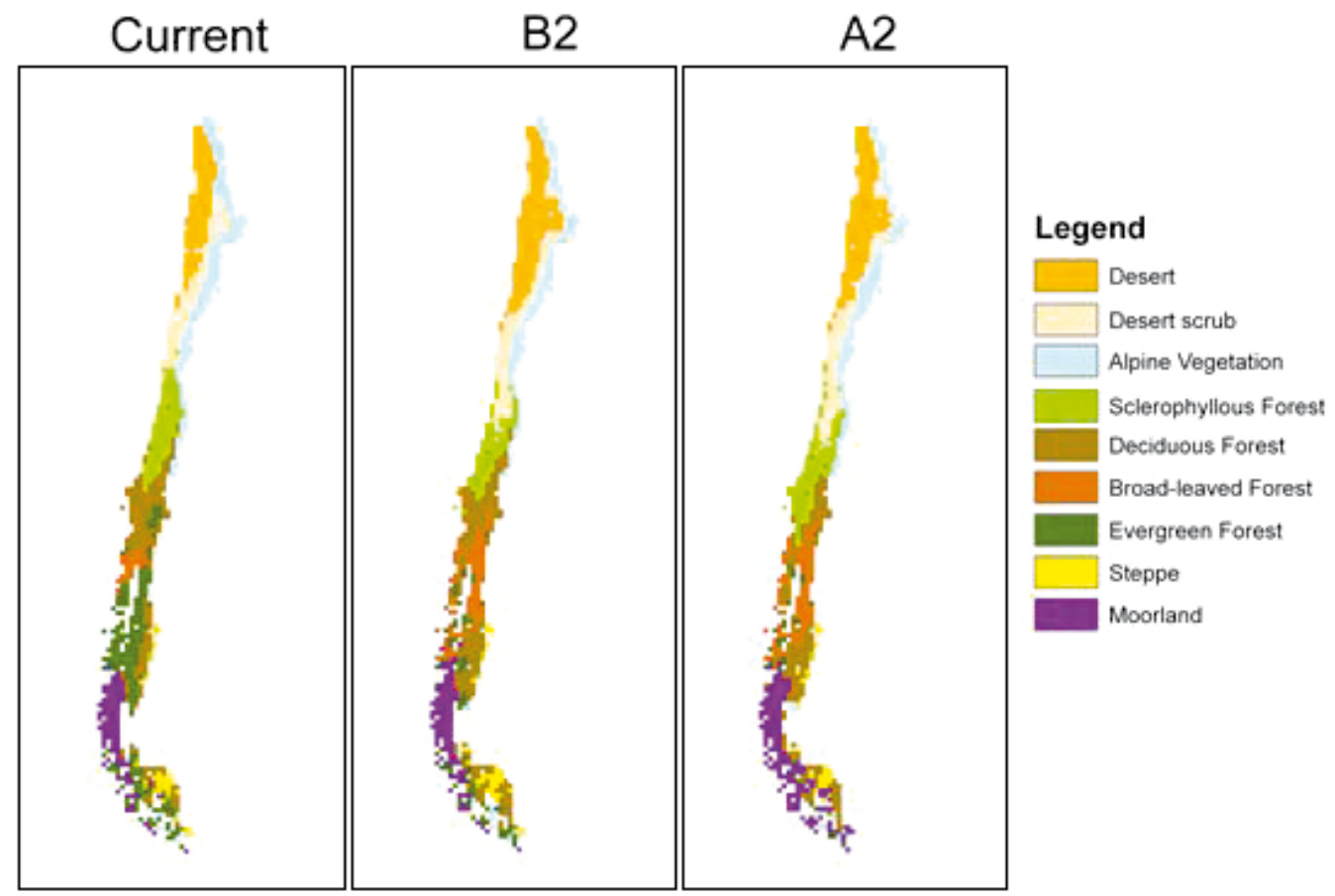

Fig. 1. Current distribution and climate change scenarios projections (B2 and A2) for vegetation types of Chile.

(Tmean, Tmin, T max, pp, h), using year 2080 as a cut-off date. Each vegetation type was modeled separately, first as a probability value of suitability which was transformed to a binary (presence/absence) map using maximum training sensitivity plus a specificity threshold (Liu et al. 2005). In the case of overlapped projection areas, we proceeded to leave the vegetation type with the higher threshold value. Transition matrices were developed for the A2 and B2 scenarios in order to determine the final vegetational outcomes.

\section{RESULTS}

The main predictions (Fig. 1) deriving from the transition matrices (Table 1) for this first Chilean country-wide modeling attempt (averaging the two scenarios) can be summarized as follows. Overall we found numerous transitions between vegetation types. The alpine belt (including the area of permanent snow), found above treeline or its equivalent along the length of the Andes, is predicted to loose around $18 \%$ of its surface area as a result of upward movement of this vegetation zone and replacement at its lower edge by desert scrub and forest. However, if upward migration of plants into the area of permanent snow (included in this belt) is possible, the true reduction in alpine vegetation is likely to be much lower than revealed by this figure. Desert scrub, found in the I-IV Regions is predicted to extend southward and increase in abundance by around $16 \%$. At the same time, the absolute desert is predicted to extend much further southward of its present latitude and expand in size by about 44\%. The situation for the forests of Chile turned out to be complex with one type expanding greatly at the expense of others. Sclerophyllous forest, centered on the Mediterranean biodiversity hotspot area, is predicted to move southward; however, its total extent will not be greatly altered, as a result of the northern extreme of the deciduous forest zone being replaced by this vegetation type. Likewise, although it is predicted to move southward, little change is expected in the total area covered by Deciduous Forest on account of this type of forest occupying part of the area now occupied by Evergreen Forest (North Patagonian Rainforest and Magellanic rainforest). The greatest changes expected for forests involve a sizable increase in the area presently occupied by Broadleaved Forest (Valdivian rainforest) ( $>3$ times 
Table 1. Transition matrix for each climate change scenario, expressed as a percentage of change of pixels number for each vegetation type.

\begin{tabular}{|c|c|c|c|c|c|c|c|c|c|}
\hline Scenario B2 & Desert & $\begin{array}{l}\text { Desert } \\
\text { Scrub }\end{array}$ & $\begin{array}{c}\text { Alpine } \\
\text { Vegetation }\end{array}$ & $\begin{array}{l}\text { Sclerophyllous } \\
\text { Forest }\end{array}$ & $\begin{array}{l}\text { Deciduous } \\
\text { Forest }\end{array}$ & $\begin{array}{l}\text { Broad-leaved } \\
\text { Forest }\end{array}$ & $\begin{array}{l}\text { Evergreen } \\
\text { Forest }\end{array}$ & Steppe & Moorland \\
\hline Desert & 63,5 & 34,0 & 2,5 & & & & & & \\
\hline Desert Scrub & 4,8 & 41,4 & 26,2 & 26,9 & 0,7 & & & & \\
\hline Alpine Vegetation & & 2,4 & 94,1 & 0,6 & 1,2 & & 1,8 & & \\
\hline Sclerophyll Forest & & & 6,3 & 70,8 & 22,9 & & & & \\
\hline Deciduous Forest & & & 1,7 & 0,8 & 63,8 & 2,9 & 27,9 & 2,1 & 2,0 \\
\hline Broad-leaved Forest & & & & & 23,7 & 21,6 & 54,6 & & \\
\hline Evergreen Forest & & & & & 1,4 & 2,9 & 94,2 & & 1,0 \\
\hline Steppe & & & & & 15,6 & & 3,1 & 75,0 & 2,0 \\
\hline Moorland & & & & & & & 9,1 & & 90,9 \\
\hline Scenario A2 & Desert & $\begin{array}{l}\text { Desert } \\
\text { Scrub }\end{array}$ & $\begin{array}{c}\text { Alpine } \\
\text { Vegetation }\end{array}$ & $\begin{array}{l}\text { Sclerophyllous } \\
\text { Forest }\end{array}$ & $\begin{array}{l}\text { Deciduous } \\
\text { Forest }\end{array}$ & $\begin{array}{l}\text { Broad-leaved } \\
\text { Forest }\end{array}$ & $\begin{array}{l}\text { Evergreen } \\
\text { Forest }\end{array}$ & Steppe & Moorland \\
\hline Desert & 66,8 & 29,9 & 3,2 & & & & & 0,0 & \\
\hline Desert Scrub & 4,3 & 42,0 & 22,8 & 30,2 & 0,6 & & 0,0 & & \\
\hline Alpine Vegetation & & 3,9 & 92,8 & 0,6 & 0,6 & & 2,2 & & \\
\hline Sclerophyll Forest & 1,6 & 0,8 & & 46,0 & 51,6 & & & & \\
\hline Deciduous Forest & & & 0,5 & 0,5 & 57,6 & 3,8 & 34,2 & 3,3 & \\
\hline Broad-leaved Forest & & & & & 19,8 & 18,9 & 60,4 & & 0,9 \\
\hline Evergreen Forest & & & & & & 9,4 & 87,5 & & 3,1 \\
\hline Steppe & & & & & 33,3 & & & 66,7 & \\
\hline Moorland & & & 0,7 & & 3,4 & & 27,4 & 4,8 & 63,7 \\
\hline
\end{tabular}

the original), mainly at the expense of development of this type of forest in the area of the cool temperate Evergreen Forest (Magellanic rainforest and North Patagonian rainforest) and Deciduous forest, both of which are presently found at higher latitudes and extends to greater altitudes. Overall, Evergreen Forest, as a result of the last trend, and further encroachment into by Deciduous Forest and Moorland, is predicted to become reduced to $25 \%$ of its present area on average, although this result is strongly heavily influenced by the results of the A2 scenario in the case of Moorland. Concomitantly Moorland increases to around 30\% over its present area, again, a result heavily influenced by the A2 scenario. These last results were surprising and are possibly, in part, due to the difficulty of separating Moorland from Evergreen Forest and the technical aspects of the application of threshold values. On average, steppe vegetation experiences minor reduction.

\section{DISCUSSION}

Modeling suggests that climate change will produce major changes in the distribution of Chile's major vegetation types. It is well to recognize that the current models used to predict vegetation change under climate change are simplistic, to the extent that there are numerous associated uncertainties. The first kind of uncertainty stems from the accuracy and lack of spatial resolution of climatic models such as the PRECIS model. PRECIS is but one of several climate change models, and clearly more work is needed to run analyses using different additional models. However, there are also numerous uncertainties that pertain to the biological realm. First, bioclimatic envelope methods like MAXENT force future climatic conditions to match with current climatic conditions that reflect the ecological conditions in current vegetation types, whereas in reality some "de novo" combinations of climate conditions are likely to rise, leading to the development of novel vegetation types, rather that wholesale migration of the existing types. Secondly, not being able to incorporate the potential fertilizing effect of increased $\mathrm{CO}_{2}$ on vegetation constitutes a serious limitation of most current modeling exercises be they at the level of vegetation belts or for individual species. Increased plant growth as a result of $\mathrm{CO}_{2}$ fertilization could strongly buffer species again climate change through 
higher growth and reproduction rates, leading to increased capacity to spread across the landscape, or simply increased capacity to survive and adapt locally. Thirdly, in using potential vegetation types, as we have been forced to do here because of the limited spatial scale of the climatic model, the current modeling effort cannot account for the impacts of barriers to dispersal resulting from current land use patterns. The high degree of fragmentation of the woody sclerophyllous forest matrix in central Chile, and the intensely cultivated Central Valley separating the Coast Range from the Andean mountains, in particular, are likely to impede movement of plant and animal species across the landscape to their predicted areas of occupation, resulting in possible local extinction in some species or at least much slower migration than predicted by the models. For plants, such dispersal barriers are more likely to be manifest among herbaceous species than among woody species, where in the latter, bird dispersal tends to be more common. Modeling exercises of the kind presented here, moreover, fail to take into account such processes as plant pollination which depends on interactions with other groups of organisms and the fact that obligately outcrossing species find it difficult to disperse over long distances because of the requirement of biparental reproduction. Finally, modeling exercises fail to take into account the dynamics of plant establishment. How a plant species reacts to increased temperature and changes in precipitation at the establishment phase is a critical factor in terms of adaptation to climate change. In the Chilean Andes, warming experiments have shown that diverse responses are found within the same species depending on altitude. Moreover, earlier flowering times, a shortening in flower longevity and most importantly, lower reproductive output have recently been experimentally detected in Rhodophiala rhodolirion in a FONDECYT project directed by MTK (Josefina Cabezas, unpublished results). Given all these caveats, it is not easy to determine whether it biologically realistic to expect such radical changes in the vegetation of Chile by the Year 2080 as suggested by the models.

The kinds of uncertainties mentioned above constitute a problem that cannot be solved without a significant and costly effort into additional scientific research and monitoring. The models presented here are best considered as working hypotheses to be tested with real-world information. An appropriate way forward would be to establish long-term biodiversity monitoring field sites at various locations throughout the length of Chile and on Antarctica so as to be able to arrive at better predictions and inform policy makers and the conservation community. This requires a coordinated effort on the part of the Chilean government, national funding agencies, and academia, and above all, a willingness to maintain such costly field and human infrastructure well into the future. In this respect, National Parks and their rangers have a vital role to play in determining the future of Chile's vegetation under climate change. Park guides should be trained to recognize, georeference, report and monitor any new incoming plant and animal species, with such information being fed immediately into a centralized data base.

The world's protected area system has grown exponentially over the past 50 years and constitutes a major investment in biodiversity conservation made by society and an important source of non-extractive economic activities for society. Governments and managers worldwide are now concerned that climate change will have major impacts on protected areas and on the economic benefits tourism brings to their economies. Apart from esthetic changes engendered by some vegetation changes, from a strictly conservation perspective, vegetation transitions within the protected area system driven by climate change could alter the relative proportions of each vegetation type that are protected, to the extent of favoring some vegetation types and to the detriment of others. Needless to say, any losers during this redistribution phase will affect a nation's plans to protect a target proportion of each vegetation type, whereas winners will facilitate this task. Using the models mentioned above, we arrived at a rough estimate of what changes are to be expected in the protection of Chile's main vegetation types over the next 70 years under the A2 and B2 scenarios. The overall situation for the protection of the changed spatial distribution of Chilean vegetation points to some winners and losers. On average, a sizable proportional increase in protection is expected for Broadleaved Forest and Desert Scrub, although in the last case the absolute increase is minor. More modest increases are found in the case of Sclerophyllous Forest, Deciduous Forest and Steppe. To the contrary, a drop in protection is expected for Moorland. This last drop is probably 
not very significant given the very high proportion of this vegetation type that comes under protection in the XI and XII Regions. The level of protection for Evergreen Forest, Alpine and Desert remains similar to at present, although as mentioned earlier, Evergreen Forest is predicted to experience notable overall reduction.

\section{ACKNOWLEDGMENTS}

Work funded by PFB-23, ICM P05-002 and FONDECYT 1085013.

\section{LITERATURA CITADA}

DGF, 2006. Estudio de la variabilidad Climática en Chile para el Siglo XXI. Informe Final, Departamento de Geofísica, Universidad de Chile, Santiago, $71 \mathrm{p}$.

Fitter, A. H., \& Fitter, R. S. R. 2002. Rapid changes in flowering time in British plants. Science, 296(5573): 1689-1691

IPCC, 2007. Climate Change 2007: Impacts, Adaptation, and Vulnerability. Contribution of Working Group II to the Fourth Assessment Report of the Intergovernmental Panel on Climate
Change [Parry, Martin L., Canziani, Osvaldo F., Palutikof, Jean P., van der Linden, Paul J., and Hanson, Clair E. (eds.)]. Cambridge University Press, Cambridge, 1000 pp.

Jones R. G., Noger M., Hassell D. C., Hudson D., Wilson S., Jenkins G., and Mitchell, J. 2004. Generating high resolution climate change scenarios using PRECIS. Met Offrice Hadley Center, Exeter, 40 p.

Lenoir, J., Gégout, J. C., Marquet, P. a, de Ruffray, P., \& Brisse, H. 2008. A significant upward shift in plant species optimum elevation during the 20th century. Science, 320(5884): 1768-1771.

Liu, C., Berry, P. M., Dawson, T. P., \& Pearson, R. G. 2005. Selecting thresholds of occurrence in the prediction of species distributions. Ecography, 28(3): 385-393

Luebert, F. \& Pliscoff, P. 2006. Sinopsis bioclimática y vegetacional de Chile. Editorial Universitaria, Santiago. 316 p.

Phillips, S., Anderson, R., \& Schapire, R. 2006. Maximum entropy modeling of species geographic distributions. Ecological Modelling, 190(3-4), 231-259 